Ladouceur, L. (2014). Bilingual performance and surtitles: translating linguistic and cultural duality in Canada. Linguistica Antverpiensia, New Series. Themes in Translation Studies, 13, 4560 .

\title{
Bilingual performance and surtitles: translating linguistic and cultural duality in Canada
}

\section{Louise Ladouceur}

University of Alberta, Canada

louise.ladouceur@ualberta.ca

Translated from the French by Richard Lebeau

In Canada, theatre artists living in a linguistic minority context, such as Francophones in Western Canada and Anglophones in Quebec, are bilingual out of necessity. They have recently explored their bilingualism in playwriting and in performing plays that display various degrees of heterolingualism. This article focuses on the emergence of a bilingual theatre in Canada and the challenges it poses for translation. Surtitles are an asset for these heterolingual plays, allowing them to reach a wider audience without erasing the linguistic and cultural specificity of the original production. The use of surtitles has led to experiments in which translation exceeds its primary function and takes on a creative role within the performance. This opens the way to the exploration of new theatrical aesthetics that showcase the linguistic duality at the heart of the Canadian reality.

\section{Introduction}

For minority language communities, theatre is a privileged art form. Not only does it permit a threatened language to resonate throughout a public space, but it does so with the specific orality of the community being represented. In Canada, where French and English are the two official languages, Francophones are in a minority situation outside of Quebec, whereas Anglophones find themselves in this position within Quebec's borders. Even though bilingualism is a necessity of daily life for these official-language minorities, it has rarely found its way onto the stage until just recently. Over the last few years, Franco-Canadian artists in the West and their Anglo-Québécois counterparts have utilized their linguistic resources in the creation of dramatic works that integrate their bilingualism in a variety of ways representative of the conditions from which these works emerge. In order to reach audiences lacking the multilingual resources necessary to understand the bilingual dialogue, these productions often rely upon translation in the form of surtitles added to the performance. Within these productions, the surtitles occasionally attain a certain autonomy and convey new messages, thus delivering a dual reading of the performance that is accessible only to the bilingual members of the audience. 
This article focuses on the emergence of a bilingual theatre in Canada, on the audacious new aesthetic that it advances, and on the challenges it poses for translation. In these heterolingual texts, the languages overlap one another, each at once a source language and a target language. Destined to be performed on stage, these forays into the intersection of languages require a creative approach that redefines the function of translation.

\section{Canadian context}

In Canada, French speakers represent approximately $31 \%$ of the population as of 2011. ${ }^{1}$ This total includes $12.5 \%$ monolingual Francophones, almost all of whom reside in Quebec, the centre of Canada's Francophonie. It also includes those who are bilingual $(17.2 \%)$, most of whom are concentrated in Quebec (12.2\%) and in the neighbouring provinces of Ontario $(0.13 \%)$ and New Brunswick $(0.2 \%)$. Historically, Quebec's bilingual population consisted mainly of Francophones who had acquired English as a second language, but recent studies show an increase in bilingual Anglophones in Quebec. ${ }^{2}$ Following the adoption of the Charter of the French Language in 1977, which established French as the sole official language in Quebec, Anglophones had to learn French to more effectively enter the workforce. According to data compiled in 2011, they now constitute the majority of the bilingual population in Quebec.

On the other hand, the Western part of the country is predominantly monolingual Anglophone. In the four Western provinces of Manitoba, Saskatchewan, Alberta and British Columbia, only $2 \%$ of the population speaks French. These Francophones must be bilingual in order to function within this predominantly-monolingual, Englishspeaking society. They congregate in certain cities that have a large enough Francophone population to receive services in French, the most important of which are Winnipeg in Manitoba and Edmonton in Alberta. Bilingual out of necessity, the Francophones of Western Canada have long considered their bilingualism a necessary evil, a contaminating influence on the French language. Promoted mainly by the Québécois, the perception that bilingualism is harmful has taken hold among other Canadian Francophones. Anchored in a Québécois context where French remains the language of the majority and a vehicular language within the public space, this point of view fails to reflect the reality of the small Francophone communities outside of Quebec. Within these minority contexts, where it is impossible to live entirely in French, bilingualism fulfills another function: rather than being detrimental to French, it serves to preserve it, inasmuch as being bilingual constitutes the condition sine qua non for remaining Francophone. This is the paradox of 
bilingualism, which is at once a threat and an essential condition for the survival of a minority language.

Thus, for a long while, Western Canadian Francophones refrained from incorporating their bilingualism into their theatre productions as it was seen as an emblem of the deterioration of French. Two phenomena would however contribute to modifying this perception. Firstly, the fact that Quebec dissociated itself from other Canadian Francophone communities in order to reclaim a territorial autonomy during the États généraux du Canada français, which took place from 1966 to 1969. According to Jules Tessier, since the language was no longer seen as an agent of unification for French Canada, Francophones outside of Quebec felt more at ease to explore their bilingual resources (Tessier, 2001, p. 31.) Thereafter, globalisation of the marketplace bestowed an incontestable added value upon bilingualism, permitting Franco-Canadians to invest their linguistic resources in the new world economy that has adopted English as a lingua franca (Heller \& Labrie, 2003, p. 21). Certain playwrights subsequently displayed their bilingualism in a more pronounced fashion before staking their claim to it as a fundamental component of their identity.

\section{Vernacular language and theatre of identity}

Having embraced the mission of preserving the French language from assimilation by English through offering an idealized linguistic and cultural model, most often borrowed from France's repertoire, FrancoCanadian theatre acquired another function at the beginning of the 1970s. It was the period when the colloquial language, the language of the people, came to dominate Francophone stages in Canada and became the emblem of a new theatre wishing to affirm a Francophone identity through the use of an idiom distinct from standard French. ${ }^{3}$ As demonstrated by Pascale Casanova in The World Republic of Letters, in the absence of an alternative language that could serve to affirm a specific literary identity, North American Francophone writers had to create a new French idiom "through the littérarisation of oral practices [...] calling for the use of a specific language freed from French norms - one that was oral, popular, and full of slang" (2004, pp. 282-283). Because it bears the marks of the way in which a society appropriates language, this idiom then functions as a "'vernacular language', local, spoken spontaneously, used less as a means of communication than of communion and [...] considered as a mother tongue (or native tongue)" (Gobard, 1976, p. 34, my translation). In Canada, this vernacular serves to affirm the linguistic identity specific to each Franco-Canadian community. Beginning in 1968, the recourse to the vernacular language would gain sway not only in dramatic writing, but also in its translation. As a result of the establishment of the Aid to Translation Program by the Canada Council 
for the Arts in 1972, the number of translations increased rapidly and the majority of English plays translated into French between 1972 and 1985 called upon the vernacular (Ladouceur, 2005, 2012a). This popular language, and the translation strategies resulting from its use, varies however from one region to the other inasmuch as they are subject to exceedingly different conditions according to their geographic location within the vast confines of Canada.

If Canada's vernacular Francophone languages maintain an evident relationship arising from historic conditions that they share, they nonetheless distinguish themselves from one another according to the degree of heterolingualism that they display. This heterolingualism manifests itself through more or less pronounced ${ }^{4}$ French-English codeswitching and a "prosodie anglaise [English prosody]" (Walker, 2005, p. 198) resulting from borrowing the pronunciation of certain sounds and their melodic arrangement à l'anglaise. In Ontario, Francophone playwrights hesitate to display their bilingualism on stage for geolinguistic reasons: their proximity to Quebec provides certain advantages in terms of a linguistic vitality, but it also imposes models that are difficult to circumvent. For Franco-Ontarian authors, Quebec exercises an enormous power of attraction and it is impossible to escape its cultural and linguistic influence. Given that bilingualism is not well received on Quebec stages, it is in their interest to refrain from exhibiting an overly pronounced bilingualism in their plays if they wish to gain a foothold in the Quebec market, as was the case for Franco-Ontarian Jean Marc Dalpé.

Dalpé's first solo creation, Le chien, was initially staged in Sudbury, Ontario in 1987. The following year it was successfully produced in Montreal and was subsequently awarded the prestigious Governor General's Award. The play's language is easily exportable to the highly influential Quebec market as it utilizes a vernacular similar to Québécois joual and contains only rare examples of code-switching. The most important instance of code-switching in the play occurs when the father describes the birth of his adopted daughter on the day when strangers knocked at his door:

PÈRE - Fait que j'les laisse entrer. 'Was tryin' to get to the hospital, ya see.' J'ai amené la femme tu-suite sur notre lit. 'Goddamn car swerved in front of us, we went down into the ditch just over here. Fuckin asshole didn't even stop!' Là, à lumière pis proche d'elle, j'ai vu que la femme, ben c'était vraiment une fille. J'veux dire, a l'avait l'air d'avoir dix-huit ou dix-neuf ans, même pas. J'sais pas trop. (Dalpé, 1987, p. 59, italics in text)

The code-switching in this instance attests to a context where French is spoken at home while English is the language of the public sphere, represented here by the stranger. But the presence of English in this 
dialogue is incidental: it could be deleted with little effect on the coherence of the narrative, the necessary information having been delivered in French. This is an example of a minimal and incidental heterolingualism, which results in the play being easily understood by a mostly monolingual Québécois public during its Montreal production.

The English translation of the play, completed by Maureen Labonté and Dalpé himself, both of whom are Franco-Ontarian, was produced in Toronto in 1988 under the same title Le Chien. As shown in the excerpt below, it employs a highly marked colloquial language, but the code-switching has been removed in favour of a monolingual English text:

FATHER - So I let them in. "Was tryin' to get to the hospital, ya see." So right away, I lead the woman into our bedroom so she can lay down. "Goddamn car swerved in front of us, we went into the ditch just over there. Fuckin' asshole didn't even stop!" Then, in the light, and close up, I could see that the woman was really just a girl. I mean, she looked eighteen or nineteen, maybe not even that old. I wasn't too sure. (Dalpé, 1988, pp. 74-75)

Not only were the translators bilingual, they were well aware of Anglophone culture and they knew the audience whom they were addressing. It was unthinkable for them to burden the English version with a code-switching that would strike a false note or render the text exotic and in doing so deprive it of its verisimilitude. If this monolingual translation managed to avoid the pitfall of exoticism, it did however cancel out the linguistic duality of the original text.

Heterolingualism poses a sizeable challenge for theatre translation. Inasmuch as the text is destined to be performed, the message delivered on stage must be immediately understood, without recourse to dictionaries, footnotes or other linguistic supports. The translation must respect the theatrical aesthetic of the play and of a specific production conceived by a director, stage designer and other artists contributing to the final product performed on stage. The actors, in turn, will orally deliver the text with their own voices, accents, intonations and body language. This collective source message will be received by a collective receptor, the audience gathered in the theatre. The theatrical nature of the text imposes parameters on the translation that heterolingualism can only exacerbate. In the case of Le Chien, the dialogue had to retain a certain verisimilitude for the target audience, in this case consisting mostly of monolingual Torontonian Anglophones. Inasmuch as the heterolingualism was minimal and fulfilled an incidental function in the source text, it was not only possible but also necessary to delete it in the translation. In doing so, however, the play was divested of the linguistic duality inherent to the context from which it sprang and which it represented through code-switching. 
The translation strategy that consists of erasing or reducing codeswitching cannot however be applied to dramatic texts in which heterolingualism fulfills an important diegetic function and serves to advance the action through dialogue that springs from a realistic aesthetic. If the splintered narration of post-dramatic works easily lends itself to experiments wherein the translation embarks upon a "metatheatrical" playfulness" (Carlson, 2006, p. 203), this is not the case for dialogue based on a certain verisimilitude that must be retained in the translation. Because the theatre text is destined to be performed, the translation must also conform to the theatricality of a given production, which is to say the play's direction, the style of acting, and the sought-after effects in relation to the targeted audience. The difficulty of translating heterolingual texts where several source languages become target languages and vice versa, and where new meanings spring up where the languages intersect, is thus heightened for dramatic texts destined to be performed on stage. This is the challenge faced by Franco-Canadian artists who explore their bilingual resources and the freedom of moving from one language to the other not only within the text, but also in its translation and performance.

\section{English surtitles in Western Canada}

Since 2007, English surtitles have been employed in Western Canadian Francophone theatres. ${ }^{5}$ For these small theatres barely surviving on the margin of the dominant Anglophone institution, this mode of translation offers several advantages. Not only does it allow them to reach a vast, heretofore inaccessible English-speaking public, but it does so while retaining the French language or bilingual dialogue of the original. Rather than erasing the linguistic codes and cultural references unfamiliar to the target audience, as is the case with conventional translation, which substitutes the translated version for the original text, surtitling enables this alterity to be seen and to be heard. It allows the audience to receive the performance in its original form and to access works that would otherwise remain unintelligible.

If the surtitles represent an asset for a theatrical production, to the extent that they allow it to be presented as it is to various audiences, they are subject to constraints of faithfulness and economy noticeably different from those of conventional translation. The latter exists autonomously from the source text, which allows the translator to modify considerably the contents or structure of the source text in the aim of improving the target audience's comprehension. One cannot take such liberties with surtitles: they must be closely linked to the source text, as the different versions are present simultaneously on stage. Inasmuch as the audience can hear the source text delivered orally and read its translated version at the same time, the latter must correspond to the original in order not to confuse or distract bilingual spectators able to compare both messages. 
Thus, existing translations of a play are often of limited use for surtitling, as the versions they propose can differ considerably from the source text. ${ }^{6}$

Surtitles, "forcing spectators to shift their focus, even if momentarily, away from the stage, are much more actively disruptive, since they are directly competing with other stimuli to the visual channel, leaving unimpeded the auditory channel" (Carlson, 2006, p. 197). In order to limit such a disruptive effect, surtitles are obliged to seek out an economy in form, to eliminate information deemed superfluous, and to privilege coding that can be quickly read. For example, it is preferable to express numbers with numerals (25) rather than words (twenty-five). One aims for a maximum efficiency in order to reduce the demands placed on the eye. The surtitles must be projected in coordination with the actors' performance and in a manner that makes them easy to read.

Yvonne Griesel (2005, p. 6) has identified three possible target audiences for a source-language production accompanied by surtitles: a) target-language audience, b) source-language audience, c) audience with knowledge of source and target languages. In the case of multilingual plays, there can be multiple source and target languages, any one of which could be easily substituted for another. As these three forms of communication unfold concurrently, the play could be perceived differently according to the linguistic profile of the recipient. This divergence between the three ways a surtitled play is received has been the subject of experiments that use surtitles not only to reproduce the message delivered on stage, but to create new messages. In doing so, they exceed their primary supportive function to assume a creative role within the original matrix of the performance, as was the case for the 2009 production of Marc Prescott's Sex, Lies et les Franco-Manitobains, which is discussed below.

\section{Playful surtitles and bilingual theatre ${ }^{7}$}

Created in 1993 in Winnipeg, Manitoba, Prescott's Sex, Lies et les Franco-Manitobains presents us with a young woman (Elle) who receives an unexpected visit from two burglars on Christmas Eve. The first burglar is a bilingual Francophone (Lui) and the second, a monolingual Anglophone (Him). As the latter speaks and understands only English, he must be addressed in English or have any exchanges in French between the other two characters translated for him. The constant code-switching from one language to the other allows for quid pro quos, substitutions and wordplay that require a thorough knowledge of the two languages to be understood. This enables the bilingual Francophone characters to mislead the monolingual Anglophone burglar, thus underlining the advantages afforded them by their bilingualism, as is illustrated in the following excerpt wherein the Anglophone asks that the young woman's personal diary written in French be read and translated for him: 
LUI - [reading the diary] "Je me demande si un jour je pourrai me donner à un homme. Pour l'instant, je devrai me contenter de mes fantasmes en attendant mon prince charmant". (À elle.) Comment ça tu pourrais pas?

ELLE - C'est pas de tes affaires.

HIM - What does it say?

LUI - It says she couldn't.

HIM - Couldn't what?

LUI - Couldn't ...Euh... Couldn't join him in his exploration of the continent down under because...

HIM - Because?

LUI - ...because. (Rapidement)...because she didn't have any experience, she had never been to Australia and she didn't like kangaroos. (Prescott, 2001, pp. 74-75, italics in text)

In this same play, Prescott sketches a critical portrait of FrancoManitoban society, and especially of the elite who wish to advance the cause of French by denying their bilingualism, as can be seen in this exchange between Elle, who works within the protected milieu of a French school, and Lui, an apprentice burglar who lays claim to his linguistic hybridity:

ELLE - Je n'ai pas besoin de vivre au Québec pour vivre en français! Je peux la vivre pleinement ma culture au Manitoba.

LUI - Bullshit ! Ça c'est de la bullshit pure et simple. Tu peux pas vivre en français au Manitoba. C'est mort. [...] Moé, je suis bilingue, pis tous les Franco-Manitobains que je connais sont bilingues. (Prescott, 2001, pp. 48-51, italics in text)

In the version of the play produced in Winnipeg and Edmonton in 2009, and in the revised version published by Les Éditions du Blé in 2013, Prescott goes even further in his affirmation of bilingualism and adds to the last line: "Pis c'est ça que je suis; bilingue. Pas anglophone, pas francophone: BILINGUE" (2009a, p. 51; 2013, p. 50). Sixteen years after the play's creation, the playwright has become even more radical in stating his position: retreating from any hierarchical distinction between the two languages, he lays claim to an exclusively bilingual identity.

This 2009 production also saw the addition of English surtitles fulfilling diverse functions. While most of them provided the spectator with a faithful translation of the dialogue, other "unfaithful" surtitles conveyed messages different to those delivered by the actors. Sitting on the left side of the stage, the translator worked on her computer keyboard in plain sight of the audience. While most of her surtitles faithfully translated the message delivered on stage, she would at times generate her own messages, which were primarily comments on her role as translator. Thus, when a Francophone character loudly vents his frustration by 
shouting "Fuckduhduhfuckfuck-fuckfuck" (Prescott, 2001, p. 42) to the , well known musical theme of Star Wars, the surtitle reads:

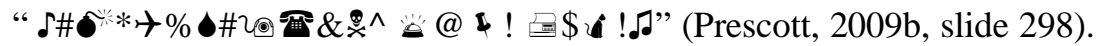
The spectators were thus invited to interpret this translation in their own way, either as an attempt at censorship or as an inability to decipher the real meaning of the source text. Whatever the case, this translative strategy essentially fulfilled a playful function inasmuch as it comically paraphrased the message transmitted orally.

Subsequently, surtitles became the voice of the translator whose discourse was superimposed over the dialogue delivered on stage. For example, she addressed the public directly to comment on the Anglophone burglar's remarks, which had not been translated as they were in English. However, Prescott's 2009 revised version of the play used a pronounced "rap slang" that remained inaccessible for older members of the audience. Noticing the problem, the translator added the following surtitle to reassure these spectators: "If you don't understand what this guy is saying, don't worry - Neither does $50 \%$ of the rest of the audience. (This message brought to you by your friendly neighbourhood surtitle)" (Prescott, 2009b, slide 602).

In the same way, the surtitles capitalized on the Francophones' bilingual and bicultural resources by proposing a written message totally different than that delivered orally, yet one that functions as a cultural equivalent. Thus, while a parody of a well-known French Christmas carol was heard onstage, the surtitles provided a parodied version of another equally well-known English carol. Here, only a bilingual and bicultural audience could appreciate the humour in the substitution. As Marvin Carlson (2006) noted,

since [the surtitle] operates as a channel of communication, an additional 'voice', especially in the case of multilanguage audiences, can use its inevitable difference from the spoken text in more original and powerful ways, for the production of additional meanings. (p. 199)

In this production, the use of playful surtitles not only amplified the bilingual and intercultural dimension of a comedy exploring the pitfalls and clichés inherent to bilingualism, but it also augmented the translation's functions. In addition to providing written equivalents in English to the oral text delivered in French, the surtitles presented new messages, thus multiplying the possible interpretations of the performance according to the linguistic resources of the audience. Some of these playful messages offered up a surplus of meaning only accessible to bilingual spectators, thus leaving monolingual spectators with a type of deficit. For the small communities needing to resort to bilingualism to protect a marginalized minority language, a translative strategy 
highlighting the benefits procured through their bilingualism at once thwarts and subverts the dominant monolingual discourse.

\section{Bilingual performance}

The ease of moving from one language and culture to the other can perhaps be seen as a characteristic of the Francophone minority communities existing on the extreme margin, aware of the impossibility in which they find themselves to function solely in French. This characteristic is illustrated textually in Prescott's play and in its surtitled version. It is also apparent in the "performance translation" of Joey Tremblay, an actor and bilingual playwright from Saskatchewan, whose play Elephant Wake was created in Edmonton in 1995 and published in an English language anthology entitled Ethnicities (1999). The play is indeed written mostly in English and contains only certain utterances in French, including some songs and allusions to the culture of a once existent Francophone village. The only character, Jean-Claude, speaks rudimentary English shaped by the influence of French, a mother tongue that for many years he has rarely had the occasion to speak. The following excerpt illustrates the substantial presence of English in the text, but it is an English shaped by French syntax, as the French in turn is influenced by the English:

JC - Mon oncle Elis, he lived in a shack in the valley with a Métis man called le Gros Cackoo. Le gros Cackoo was big and strong, eh, like a bear - but he couldn't talk good. He just make funny noise like: "guh, guh guh, guh" when he try to talk.

Mon oncle Elis said, "That one, il parle mal, mais je comprendre tous qui dit and tous qu'il y a besoin. I feed him good to keep him big and strong. He keeps me safe from all that is bad and mean in this ugly, ugly world."

When I'm little I used to walk to visit with them. Mon oncle Elis, him, he was always so excited to see me. He would dance in the kitchen. "Ooo la la! La grande visite de Ste Vierge. Il faut faire un beau gâteau. Un gâteau pour le petit môme.” (Tremblay, 2007, p. 15)

The play toured the country playing to mostly English or bilingual audiences. But, in 2010, the production was invited to the Carrefour international de théâtre in Quebec City. Sensing that for the first time his audience consisted mostly of Francophones, Joey Tremblay tailored his performance to this audience by spontaneously translating the text into French. The following is his observation on the process: 
In Quebec, the moment I stepped on stage, I could sense the francophone majority of the audience... and without pretranslating I began the monologue in French. A broken French, but the text suddenly flipped as a piece that was mostly French, with English phrases thrown in [...] It's the same experience I have going home to visit my relatives... I start speaking in French subconsciously, as that is our shared language. (Quoted in Nolette, 2012, p. 213)

What is remarkable here is that even though he knows that his French is far from perfect and replete with English, he did not hesitate to utilize it with a Francophone Québécois audience. This requires considerable audacity; even more so when translating spontaneously into a French language of which the actor has only a flawed knowledge. But Tremblay succeeded in transforming this obstacle into an asset. Faced with this broken French, the audience had to listen more attentively. Tremblay described what happened thus: "you were experiencing the play, not observing it" (Louder, 2010).

This is an instance of a translative strategy that takes place in the orality of the theatre language, as the written source text is translated orally into another spoken language. No longer relying on the text, the actor alone, while performing, adapts his bilingual resources to communicate with the audience and spontaneously modifies the interspersion of languages in which he expresses himself during the performance. The bilingual subject personified by Tremblay thus crosses the language barrier to tell his story both in English, inasmuch as his Francophone village no longer exists so he must now live in English, and in French, when he addresses an audience consisting mainly of Francophones. Moreover, each language is shaped by the presence of the other, whether in the syntax, the accent or the prosody of the spoken text. Such a heterophony does not prevent the author from being understood, it simply demands greater attention from the spectator, who thus experiences a certain strangeness in the form of expression. Already present in the source text, this strangeness, representative of a bilingual context where French and English often collide in the colloquial language, has been amplified in the target text through the effect of spontaneous translation, which obliges the spectator to listen more attentively to dialogue delivered in a manner that confounds his or her expectations.

\section{Bilingual theatre in Quebec}

Founded in Montreal in 1998 by Annabel Soutar and Alex Ivanovici, the Théâtre Porte Parole specializes in documentary theatre, which Soutar describes thus: 
[A genre] whose subjects are inspired by socially contemporary events and problems, and in which the majority of the dialogue is developed from interviews conducted with individuals effected by these events and problems. The dramatic material of documentary theatre can be equally fuelled by other sources: newspaper articles, accounts of court proceedings during a trial [...] essays or reports, televised reportage or any other documents able to provide documentation on a chosen subject. (Lévesque, 2006, p. 158, my translation)

According to Soutar, the documentary theatre that she creates crosses the language barrier: "I don't make decisions based on language. I have a documentary mission and I go and find the people that can tell the story for me and I don't care if they speak English or French" (Quoted in Ladouceur, 2012b). For the production of her play Sexy béton ${ }^{8}$, which toured the province of Quebec between 2009 and 2011, Soutar focused on the Commission of Inquiry following the 2006 collapse of the overpass on the Boulevard de la Concorde in Laval, Quebec. This tragedy, which left five people dead and six others injured, was attributed to defects in the infrastructure of the overpass, as well as to the negligence of people and organisations involved in its construction and maintenance. But no one took responsibility for what had happened. In Soutar's play, two actors, Maude and Brett, become interested in the story and begin their own investigation into why the overpass collapsed. They proceed to interview people involved in the Commission of Inquiry, as well as the families of the victims, as these families attempt to determine who is responsible and whether or not they should seek legal redress.

In the original version, Brett speaks in English and Maude in French. Thus, the narration takes place in one language or the other. In keeping with the actual event, the majority of the twenty characters on stage are Francophones and the majority of the interviews, the recordings of which are reproduced verbatim, are in French. There are four Anglophone characters as well, including Maria Mercandante and her spouse Mohamed Ashraff Umerthambi, who died in the accident. In this first version of the play, the dialogue and the interviews of the Anglophone characters remained in English. For Annabel Soutar, it is important to conserve the dialogue in the form it was gleaned from the interviews:

$[\ldots]$ words that people speak are $[\ldots]$ revealing of where they're from and, you know, their oral language. [...] I don't change the text, I don't adapt it, I don't translate it. If I interview someone in French, their text will take place in French. If I interview someone in English for the same play, I keep it in English. (Quoted in Ladouceur, 2012b) 
Théâtre Porte Parole produced this bilingual version of the play with great success in Montreal at the English Segal Centre for the Performing Arts. It was then invited to present the play at the French Théâtre DenisePelletier, which involved revising it to suit an audience consisting of Francophones not sufficiently bilingual to understand the dialogue in English. Soutar then decided to translate only the dialogue of the English narrator into French, keeping all other English dialogue and testimony in its original form, "because it is very important. One cannot translate into French the Sri-Lankan character that has difficulty speaking English, because the authenticity of his voice would be lost. But one can add surtitles to allow Francophones to follow the story" (Quoted in Ladouceur, 2012b). Since the actor playing the Anglophone narrator was bilingual, he was able to switch to French for the translated production in a French theatre.

The translated version was presented under the same title Sexy béton (Soutar, 2011) and produced on nine other French stages in Montreal and its suburbs. This translative strategy thus enabled Théâtre Porte Parole to access a sizeable theatrical market, which had previously been less than hospitable to English or bilingual productions. Within the context of Quebec, where English is a minority language, the recourse to surtitling made it possible to reach a large Francophone audience previously inaccessible. Just as with Western Canadian Francophone playwrights, Anglo-Québécois playwrights rely upon surtitling to disseminate their works to an enlarged market while retaining their linguistic and cultural specificity.

\section{Conclusion}

The distribution of official language communities throughout Canada's vast territory results in Anglophones forming a minority in Quebec, while Francophones are in the minority elsewhere in Canada, particularly in the Western provinces. Bilingual out of necessity, these minority communities have recently invested their bilingual linguistic and cultural resources in theatre creation. To circumvent the obstacles faced by bilingual texts, which can only reach a limited number of spectators, the creators have resorted to the use of surtitles. This mode of translation serves the performance of a play remarkably well, as it allows the original production to be adapted for various target audiences while conserving its specific language and theatricality.

The use of surtitles has made it possible for artists in a minority context to reach audiences and artists from outside of their community, thus instigating a critically important exchange. Submitting their work to the judgment of their English-speaking peers is a sign of vitality for Francophones in a minority context. As Lucie Hotte notes, it indicates that they are "worthy of competing with works produced elsewhere 
(which) testifies to the vitality of a community" (Hotte, 2013, p. 16, my translation). This was the case when Edmonton's L'UniThéâtre was awarded the Sterling Award 2013 for "outstanding contribution to Edmonton theatre." As mentioned in the press release announcing the award, the use of English surtitles played an essential role in this artistic recognition: "According to the nomination committee, L'UniThéâtre's initiative to present its plays with English surtitles over the last few years has had a great impact within Edmonton's theatre milieu." (L'UniThéâtre, 2013, my translation).

In Western Canada, surtitling has also been the subject of experiments in which the translation adopts new playful functions that build upon the bilingualism of the artists and the audience. This bilingualism opens the way to the exploration of new aesthetics that showcase the linguistic duality at the heart of the Canadian reality. Far from acting as an obstacle, this linguistic and cultural duality operates as a laboratory generating new forms of writing, translating and performing that go beyond the dichotomy upon which the Canadian dramatic repertoires and theatrical institutions have been founded, crossing the heretofore impassable boundaries between the French and English languages and cultures. ${ }^{9}$

\section{References}

Carlson, M. (2006). Speaking in tongues: Language at play in the theatre. Ann Arbor, MI: The University of Michigan Press.

Casanova, P. (2004). The world republic of letters. M.B. DeBevoise (Translated into English. French original La république mondiale des lettres, 1999). Cambridge, MA: Harvard University Press.

Dalpé, J. M. (1987). Le chien. Sudbury: Prise de parole.

Dalpé, J. M. (1988). Le Chien, M. Labonté \& J. M. Dalpé (translated into English, French original Le chien, 1987). Manuscript at Centre des auteurs dramatiques, Montreal, QC.

Gobard, H. (1976). L'aliénation linguistique: Analyse tétraglossique. Paris: Flammarion.

Griesel, Y. (2005). Surtitles and translation towards an integrative view of theatre translation. In H. Gerzymisch-Arbogast \& S. Nauert (Eds.), MuTra 2005 Challenges of Multidimensional Translation: Conference Proceedings. Saarbrücken,

http://www.euroconferences.info/proceedings/2005_Proceedings/2005_procee dings.html (visited on June 26, 2011).

Heller, M. \& Labrie, N. (2003). Discours et identité: La francité canadienne entre modernité et mondialisation. Fernelmont: Éditions modulaires européennes.

Hotte, L. (2013). Artiste, animateur culturel ou médiateur culturel?: Le rôle des artistes dans les communautés francophones du Canada. Minorités linguistiques et société / Linguistic Minorities and Society, 3, 7-18. 
Ladouceur, L. (2005). Making the scene: La traduction du théâtre d'une langue officielle à l'autre au Canada. Quebec, QC: Nota bene.

Ladouceur, L. (2012a). Dramatic licence: Translating theatre from one official language to the other in Canada. R. Lebeau (Translated into English. French original Making the Scene: La traduction du théâtre d'une langue officielle à l'autre au Canada, 2005). Edmonton, AB: University of Alberta Press.

Ladouceur, L. (2012b). Personal interview with Annabel Soutar, Montreal, February 10.

Lévesque, S. (2006). Chercher la réalité au coeur de la fiction: Entretien avec Annabel Soutar, JEU, revue de théâtre, 119(2), 158-162.

L'UniThéâtre (2013), Célébré par ses pairs anglophones, Press release, June 25.

Louder, D. (June 2010). Carnet de Dean Louder, http://www.septentrion.qc.ca/deanlouder/2010/06/le_fransaskois_joey_ tremblay_s.php (visited on November 23, 2012).

Nolette, N. (2012). Monodrame, récit de vie et théâtre post-identitaire de l'Ouest canadien, Recherches théâtrales au Canada, 33(2), 207-223.

Prescott, M. (2001). Big; Bullshit; Sex, Lies et les Franco-Manitobains. SaintBoniface, MB: Les Éditions du Blé.

Prescott, M. (2009a). Sex, Lies et les Franco-Manitobains, revised manuscript version. Produced by Les Chiens de Soleil, Saint-Boniface, October 28-31, and Le Théâtre au Pluriel, Edmonton, November 5-6.

Prescott, M. (2009b). Sex, Lies et les Franco-Manitobains, S. Liss \& L. Ladouceur (English surtitles. French original Sex, Lies et les Franco-Manitobains, 2001). Produced by Théâtre au Pluriel, Edmonton, November 5-6.

Prescott, M. (2013). Sex, Lies et les Franco-Manitobains, revised version, SaintBoniface, MB: Les Éditions du Blé.

Soutar, A. (2011). Sexy béton, A. Soutar (Partially translated into French with French surtitles. English original Sexy Béton, 2009).

Statistics Canada, 2011 Census, Government of Canada, "Population by knowledge of official language, by province and territory", www.statcan.gc.ca (visited on April 19, 2013).

Tessier, J. (2001). Américanité et francité: Essais critiques sur les littératures d'expression française en Amérique du Nord. Ottawa, ON: Le Nordir.

Tremblay, J. (1999). Elephant wake. In A. Nothof (Ed.) Ethnicities (pp. 170-198). Edmonton, AB: NeWest.

Tremblay, J. (2007) Elephant wake. Online revised version, http://globetheatrelive.com/+pub/tours/elephant-wake/Elephant $\% 20$ Wake\%20-\%20Script.pdf (visited on November 23, 2012).

Walker, D. C. (2005). Le français dans l'Ouest canadien. In A.Valdman, J. Auger \& D. Piston-Hatlen (Eds.). Le français en Amérique du Nord: État présent (pp. 187-205). Quebec, QC: Les Presses de l'Université Laval. 
1 The statistics are from the 2011 Census, "Population by knowledge of official language, by province and territory", Statistics Canada, Government of Canada. www.statcan.qc.ca (visited on April 19, 2013).

2 According to the Office of the Commissioner of Official Languages, recent statistics indicate a rise in the percentage of bilingual Anglophones in Quebec: http://www.ocolclo.gc.ca/html/parkin_f.php (visited on December 30, 2009).

3 For more details on the use of a colloquial variety of a language to affirm a specific linguistic identity, see Casanova, P. (2004). The world republic of letters. M.B. DeBevoise (Translated into English. French original La république mondiale des lettres, 1999). Cambridge, MA: Harvard University Press.

4 For a more detailed analysis, see Hallion Bres, S. (2006), Similarités morphosyntaxiques des parlers français de l'Ouest canadien. In R. Papen \& G. Chevalier (Eds.), Les variétés de français en Amérique du Nord: Évolution, innovation et description. Revue Canadienne de Linguistique Appliquée-Revue de l'Université de Moncton 37(2), 121.

5 The use of English surtitles by Canadian theatre companies was initiated in 2005 by Toronto's Théâtre français, followed by other Franco-Ontarian theatre companies and by Saskatoon's La Troupe du Jour in 2007, and Edmonton's L'UniThéâtre and Vancouver 's Théâtre la Seizième in 2008

6 For a more detailed analysis, see Ladouceur, L. \& S. Liss (2011). Identité bilingue et surtitres ludiques dans les théâtres francophones de l'Ouest canadien. Francophonies d'Amérique 32, 171-186, and Ladouceur, L. (2013) Surtitles take the stage in francocanadian theatre. Target, International Journal of Translation Studies 25(3), 343-364.

7 For a further analysis of the material discussed in this section, see Ladouceur, L. (2013), Exploring a bilingual aesthetics through translation in performance. In P. Ambrosi, S. Bigliazzi, \& P. Kofler (Eds.), Theatre translation in performance (pp. 11-129). London: Routledge.

8 I would like to thank Annabel Soutar for graciously providing me with the manuscript version of the play.

9 This article has received the support of the Social Sciences and Humanities Research Council of Canada. 